Kazushi Iwao, Alexander V. Zorin

\title{
Secular Fragments of Tibetan Texts found at the Main Dunhuang Collection kept at the IOM, RAS*
}

DOI 10.17816/wmo35114

Abstract: The paper introduces twelve fragments of secular texts in Tibetan found in the main collection of Dunhuang manuscripts preserved in the IOM, RAS. In regard of each fragment a physical description, provisional notes on their contents, digital copy and transliteration are provided. Since all the fragments are very short our identifications of the texts are just tentative. One of them, Дx-7759, relates to the divination with dice. The others are fragments of letters, economic documents, etc.

Key words: Dunhuang, Tibetan manuscripts, secular texts

In 2017 one of the coauthors of this paper edited eleven fragments of Tibetan Buddhist texts found at the Dunhuang Collection preserved in the Institute of Oriental Manuscripts, RAS (IOM, RAS) (ZORIN 2017). They belonged to the list of 51 items with Tibetan inscriptions identified by him in this collection. ${ }^{1}$ He classified these items into four groups: Group 1, canonical

(C) Kazushi Iwao, Ryukoku University, 2020

(C) Alexander Valerievich Zorin, Institute of Oriental Manuscripts, Russian Academy of Sciences, 2020

* Kazushi Iwao's contribution to this paper was supported by JSPS KAKENHI, Grant Number JP 19K01043.

${ }^{1}$ The main Dunhuang collection is meant here. There is also a separate collection of Tibetan texts from Dunhuang that initially consisted of the copies of Arya-aparimitāyurjñananāma-mahāyāna-sūtra and Hridaya-sūtra (SAVITSKY 1991) along with two other items that had to be transferred to other IOM collections since they had been added to this collection mistakenly. On the contrary, two other scrolls, three pothi books and two concertina books were added to it (ZORIN 2018). Since the 1990s, it had been clear that the IOM collection of Tibetan texts from Khara-Khoto also had some Dunhuang texts. Thus, T. Takeuchi discussed XT-4 as an example of a loan contract from this site (TAKEUCHI 1995: 204-207). In 2018, A. Zorin, A. Sizova and A. Turanskaya, participants of a special project aimed at cataloguing 
Buddhist texts; Group 2, fragments of documents; Group 3, tiny fragments; and Group 4, separate letters, mantras, scribbles, etc. While the 2017 text cataloged Group 1 items, the current paper addresses twelve of the thirteen items in Group $2^{2}$.

All of the fragments in Group 2 are secular texts, such as contracts, letters, and name lists. Many Tibetan texts in this group, all of which are apparently from the Dunhuang cave, are written on the back of Chinese Buddhist texts, which means that these Tibetan texts were written on reused paper in Dunhuang.

The presentation of each fragment consists of following aspects: call number $^{3}$, physical features, identification (if possible), digital copy and transliteration. Most of the fragments seem to have belonged to letters and economic documents. One item apparently contains the results of the divination with dice and one is a part of Old Tibetan Annals. We hope that our publication can help researchers find some jointing parts of these fragments in other depositories that will make it possible to analyze them with more preciseness.

In this paper, the transliteration of Tibetan texts is based on Wylie system, with the following changes and additions.

the Tibetan texts from Khara-Khoto, thoroughly checked the collection and identified 34 fragments from Dunhuang within it. These items, as well as other 10 found among unprocessed materials, were added to the collection Tibetan texts from Dunhuang, see (ZoRIN, SizovA 2019). These items have been studied by the above-mentioned group; A. Turanskaya has edited eleven fragments of Śatasāhasrikā Prajñāpāramitā (TURANSKAYA 2020). There are some secular items as well, one of them is going to be specially studied and published by K. Iwao who found a jointing part of it in the Paris collection.

${ }^{2}$ Дx-12851 was edited and analyzed in IwAO 2011. It is a part of Old Tibetan Annals, which is the different version of the Annals preserved in the British Library and Bibliothèque Nationale de France (for example, see BACOT ET AL. 1940 and DOTSON 2007). This fragment only bears the report of 703 and 704 .

We would like to add only that the smaller fragment of the item is currently kept in a separate envelope that also contains a tiny piece of paper that bears the ending of some phrase: $n g \cdot \mid$ Judging by paper and style of writing it clearly used to belong to a different manuscript.

${ }^{3}$ Original Russian letters are used: $\Phi(=\mathrm{F})$ that relates to K. K. Flug's inventory and Дx (=Dh, or Dx) that relates to the remaining part of the Dunhuang collection. We would also like to note that A. S. Zhukovskaya has been processing the entire Dunhuang collection anew and providing new call numbers to the items (they start with the letters ДХН), her aim being to unite scattered fragments of the same manuscripts. We provide these alternative call numbers for those items that have already been given them. Needless to say, the old numbers can be always used by researchers. 
$\wedge_{\mathrm{a}} \quad \mathrm{vv}^{4}$

m Symbol similar to Sanskrit anusvāra

[...] Illegible or missing letters, the number unknown

[---] Illegible letters, the number is shown by -.

$[a b c]$ Missing letters that can be reconstructed

$<$ abc $>$ Deletion

$\odot \quad$ Twofold circles which normally show the result of the eye of dice

(a) Yig mgo

i Break point

¿i Gigu written to the left of the letter it belongs to

- $\quad$ Contraction of the syllables

(!) Typo

- Empty space

Absence of tsheg

\section{1. $\Phi-230$ Verso}

The Chinese scroll, Yiqie Jing Yinyi 一切經音義. On the Verso side of the scroll, there are several small patching papers, three of which bear a Tibetan text. Apparently, this patching is a reused paper of Tibetan text. The sizes of the three patching papers are, respectively, (1) $3.8 \times 2.7 \mathrm{~cm},(2) 9 \times 5.3 \mathrm{~cm}$, and (3) $8 \times 3.8 \mathrm{~cm}$. Patching paper 2 is directly connected to 3 . Judging by the handwriting and the repeated word $\wedge$ an $t a$, all three fragments belonged to the same manuscript.

\section{Patching paper (1)}

Paper 1 is a tiny paper with three Tibetan lines. Left, top and right sides of the fragment are torn off, and the beginning and end of the text are missing. The bottom side seems to be even enough to be the original edge of the manuscript. Although the first syllable misses its left part the word $\wedge a n t a$ is certainly written here, cf. the same word in line 3 of Patching paper (2).

\footnotetext{
${ }^{4}$ This Tibetan letter is usually transliterated as $a$. However, in respect of secular texts written by Chinese inhabitants of Dunhuang it seems necessary to add some sign before $a$ to show that they could use this letter as the phonetic rendering of Chinese pronunciation ?. Such a necessity is most clearly seen in the case of the syllable ऊु్ (see text No. 7 of this paper, Дх-6721) which could be used for 陰 ?im.
} 


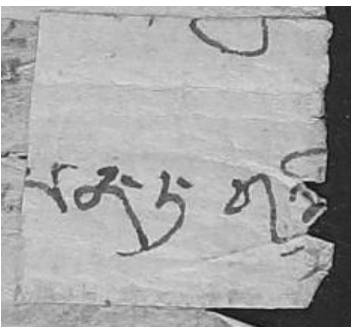

1. $[\ldots] \mathrm{u} ?[\ldots]$

2. $[\ldots][\wedge a ?] n \cdot t a \cdot g n y i[\ldots]$

\section{Patching paper (2) and (3)}

On paper 2, the bottom and left sides are torn off, the right side is directly jointed with the left side of paper 3 where the bottom side is torn off. The top side of both papers and the right side of paper 3 seem to be even enough to be original edges of the manuscript.

The text is too short to identify the content, but it seems to be either a legal document or letter draft.

The left part of the text is Patching 2, while the right is Patching 3.

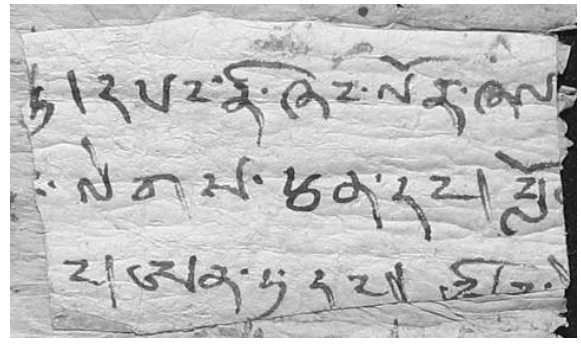

1. [...]t[e]|dpa(!)r'na'zh<ing $\cdot$ lon'zhal ${ }_{1}^{\perp}$

2. [...]'legs'tsan'dang $\mid$ blo $\mid$

3. [...]ng $\left.\right|^{\wedge}$ an'ta'dang $\mid[-] \mathrm{i}[--]_{\mid}^{\prime}$

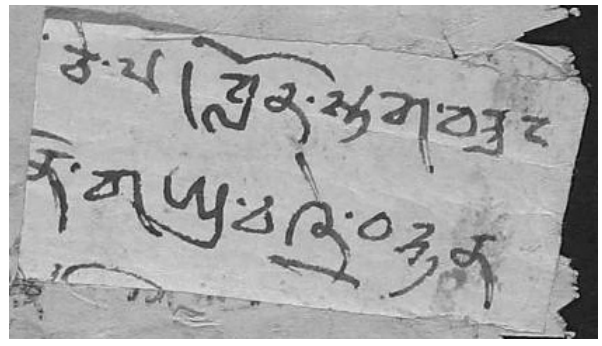

ce'pa|blon'stag bzang

n'g.yu'bzhe-r'brtan

$[-] i[\ldots]$

\section{2. Дх-5179 (ДХН 4406)}

A fragment $(13.2 / 7 \times 8.7 \mathrm{~cm})$. All sides are torn off. On the Recto side, Tibetan lines are found. Verso is blank.

\section{Recto}

Seven lines in Tibetan with standard lines. The beginning and end of the text is missing. Judging from the term such as chibs-bseb, it is probably a text concerning on a horse. See BLONDEAU 1972. 


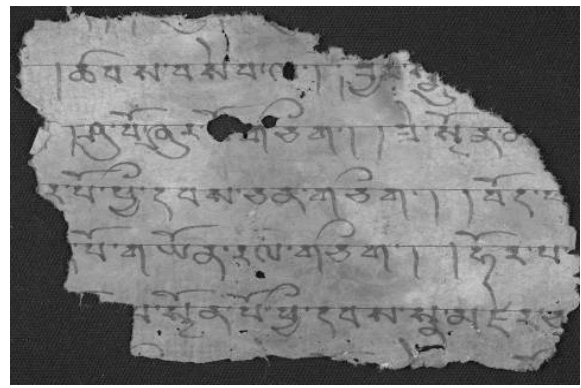

1. $[\ldots] \mathrm{u}[\ldots]$

2. [...]_chibs'bseb $\cdot$ la' $\mid \_$byang $[s] \mathrm{mu}[\ldots]$

3. [...]_shu'po'zhur'[-]o'gcIg'|_ze'sngon' $\mathrm{m}[\ldots]$

4. [...]r'po'phyI'dpas'can'gcIg || bod'ph[...]

5. [...]'po'g.yon $\cdot \mathbf{r a l} \cdot \mathrm{gcIg} \cdot \mid \_$hor $\cdot \mathrm{pa} \cdot[\ldots]$

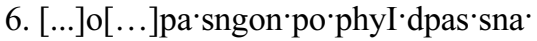
mdzer $c[\ldots]$

7. $[\ldots] \mathrm{I}[\ldots] \mathrm{e}[\ldots] \mathrm{o}[\ldots] \mathrm{e}[\ldots] \mathrm{o}[\ldots]$

Verso

blank.

\section{3. Дх-5500 (ДХН 5040)}

Fragment of scroll $(25.4 \times 40.5 \mathrm{~cm})$. The Chinese text on the Recto side and Tibetan on the Verso side.

\section{Recto}

Chinese Daoist text. A part of 8th volume of Taishang Dongyuan Shenzhou Jing太上洞淵咒經.

\section{Verso}

Four lines in Tibetan ${ }^{5}$. It is an unfinished text of the letter draft. For the format of Old Tibetan letter, see TAKEUCHI 1990.

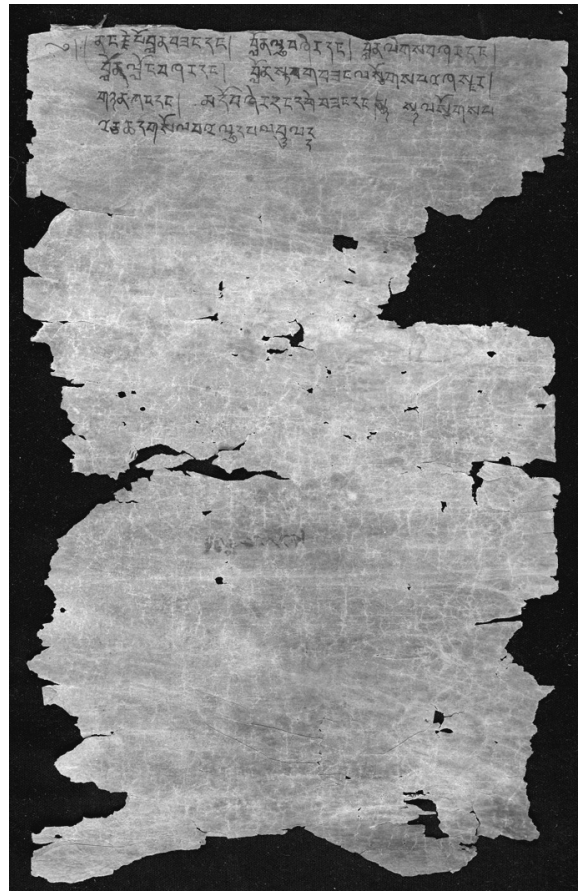

\footnotetext{
${ }^{5}$ TAI 2019: 405 states "the fragment with Uighur texts," but it is apparently Tibetan.
} 


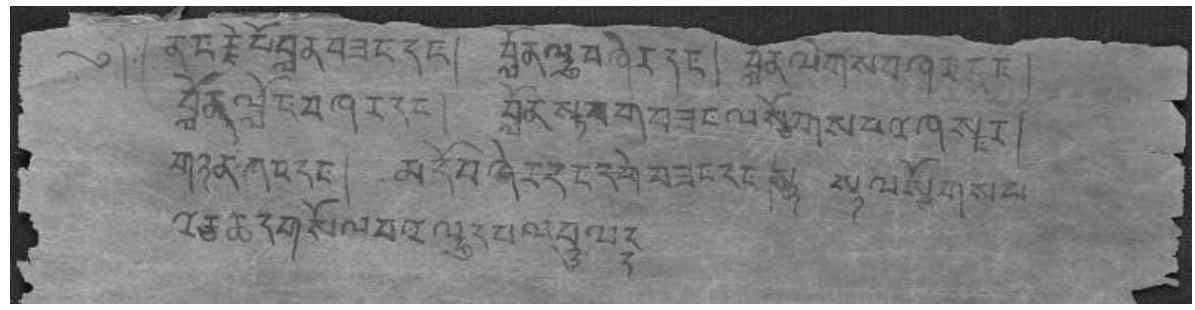

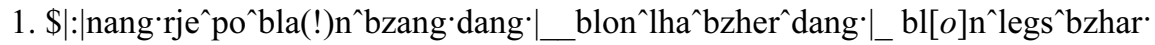
dang $\cdot$

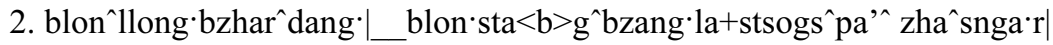

3. gnyan $\cdot$ kang $\cdot$ dang $\cdot \mid \ldots$ mdo`bzher dang $\cdot$ dge^bzang $\cdot$ dang $\cdot \mid$

$<$ snya>_snya^la+stsogs pa

4. 'rtsa`chad`gsol`ba' 'lha^dpal`bnyul - bnyu(?)|^da-ng(da-d?)

\section{4. Дх-6396 (ДХН 5878)}

A left side of an oblong sheet $(12.1 / 10.7 \times 5.6 \mathrm{~cm})$. The Tibetan text is written on the both sides of Chinese scroll.

\section{Recto}

Three lines in Tibetan. The end of the text is missing. Account of the death toll of soldiers belonged to the thousand-district named Gzong-sde ${ }^{6}$.

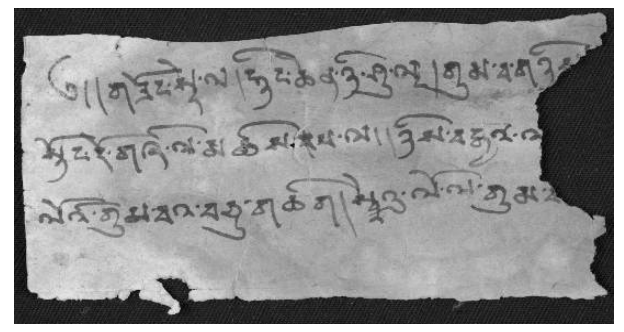

1. \$||gzong·sde·la|rnying·chen'nyi·shu' lnga $\mid$ gum $\cdot$ ba $\cdot$ gnyi $\left[s^{\cdot} \ldots\right]$

2. stong $\cdot$ do $\cdot$ gzhi $\cdot$ la $\cdot$ mchis $\cdot<$ nga? $>$ pa $\cdot$ la $\|$ nyis' brgya' 1 ? [...]

3. lo'i'gum·ba' bcu'gchig $\mid$ sbre'u'lo•la' gum $\cdot b[\ldots]$

\section{Verso}

Four lines in Chinese Buddhist text, most probably Miaofa Lianhua Jing 妙法蓮華經.

${ }^{6}$ According to Classical Tibetan sources such as Lde'u chos 'byung and Mkhas pa'i pga' ston, Gzong sde belonged to the right $r u$ (g.yas ru) in Central Tibet. Cf. IwAO 2000, 598. 


\section{5. Дx-6554}

Upper right corner of a sheet $(12.1 / 1 \times 9.2 \mathrm{~cm})$. Reusing paper of a Chinese Buddhist scroll.

\section{Recto}

Four lines in Tibetan. The beginning and the end of the text are missing. A part of letter type (1)?

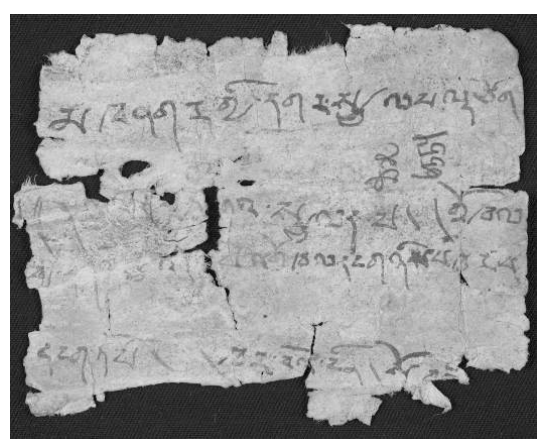

1. [...]mkhan^gar"gyi·dgar'stsal`pa^lda^cog

2. [...][-----]dka'stsald'pa|_gro^khal

3. [...]gy[i] ${ }^{\wedge} \mathrm{dka}^{\prime \wedge} \mathrm{stsal}^{\wedge} \mathrm{pa}^{\wedge}{ }^{\prime} \mathrm{gro}^{\wedge} \mathrm{khal}^{\wedge} \mathrm{dang}^{\wedge}$ gnyis^pa^khar bu

4. [...]dang^gtâpo|_|khar'ba'I'rin|so^b[-]i $[\ldots]$

\section{Verso}

Five lines in Chinese. Da Banruo Boluomiduo Jing 大般若波羅蜜多經.

\section{6. Дx-6606 and Дx-6562}

Originally one single sheet of the Chinese scroll Jingang Banruo Jing 金剛 般若經, which is divided into three fragments, Дx-6606 $(26 \times 26 \mathrm{~cm})$, Дх-6562 (36×26.2 cm), Dx6563 $(7 \times 12.3 \mathrm{~cm})^{7}$.

\section{Recto}

Chinese Buddhist text. Jingang Banruo Jing 金剛般若經.

\section{Verso}

Two lines in Tibetan. The text is an unfinished draft of contract.

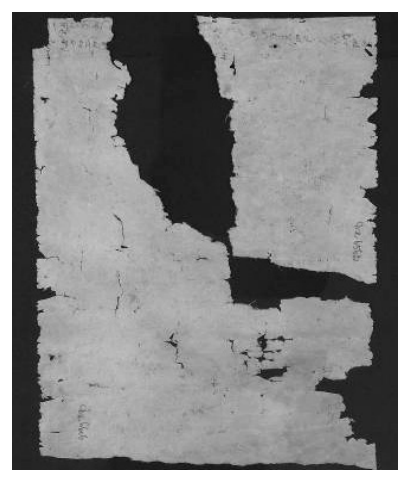

\footnotetext{
${ }^{7} \mathrm{We}$ do not provide its picture since it contains no Tibetan text.
} 


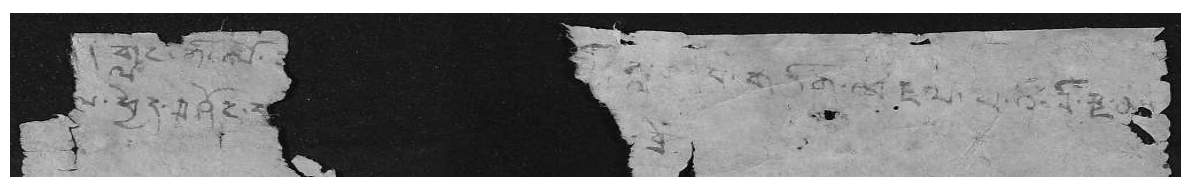

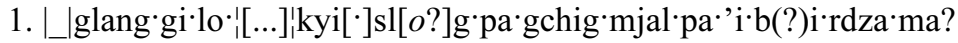

2. $[-] 1 \cdot$ phyed $\cdot<\mathrm{b}>$ shong $\cdot d$ ? $[[\ldots]] \cdot$ bre

\section{7. Дх-6721}

Fragment $(15.8 \times 15.5 \mathrm{~cm})$. Chinese text is found on the Verso side, while Tibetan text is found on both Recto and Verso sides. The Tibetan text of both sides bears the same content, a list of Chinese with the pattern of individual clan name (rus), courtesy name (mkhan), and given name (mying).

\section{Recto}

Five lines in Tibetan between two Chinese lines, which is a part of Jingang Banruo Jing 金剛般若經. The end of each line is missing.

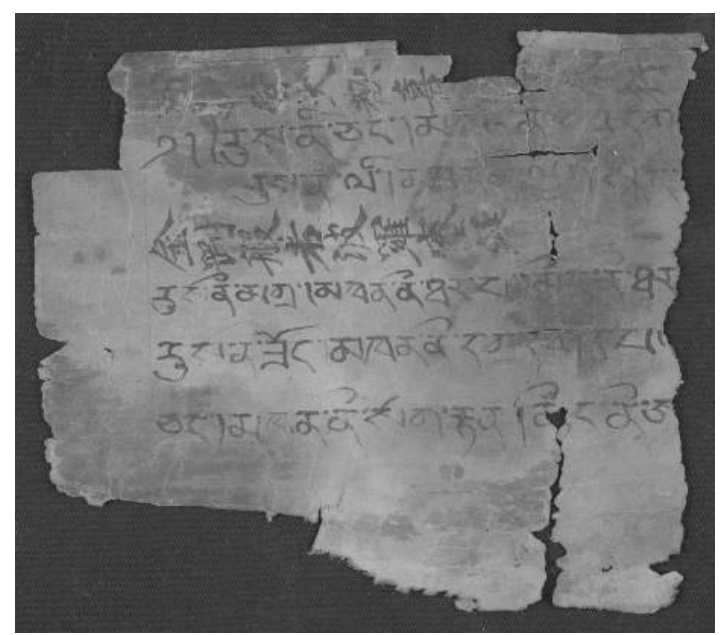

所・說皆大歡喜信受・奉行

1. $\$ \mid$ rus'ni'cang $\cdot \mid$ mkhan$\cdot n I \cdot d g r a \cdot d o g[\ldots]$

2. _ rus'nI $\cdot l i \cdot \mid$ mkhan'nI $\cdot$ lyag $\cdot$ skang $\cdot[\ldots]$

金剛般若波羅蜜多經

3. rus`nI·mgra'|mkhan'nI·thar'pa|myIng'nI·thar [...]

4. rus'nI'zong $\mid$ mkhan'nI'dgra'dog $d p a[-\ldots]$

5. cang $\cdot \mid$ mkhan $\cdot n I \cdot \operatorname{sog} \cdot r \operatorname{rtan} \mid$ myIng $\cdot n \mathrm{nI} \cdot \wedge \mathrm{a}[-\ldots]$ 


\section{Verso}

Five lines in Tibetan. The end of the text is missing.

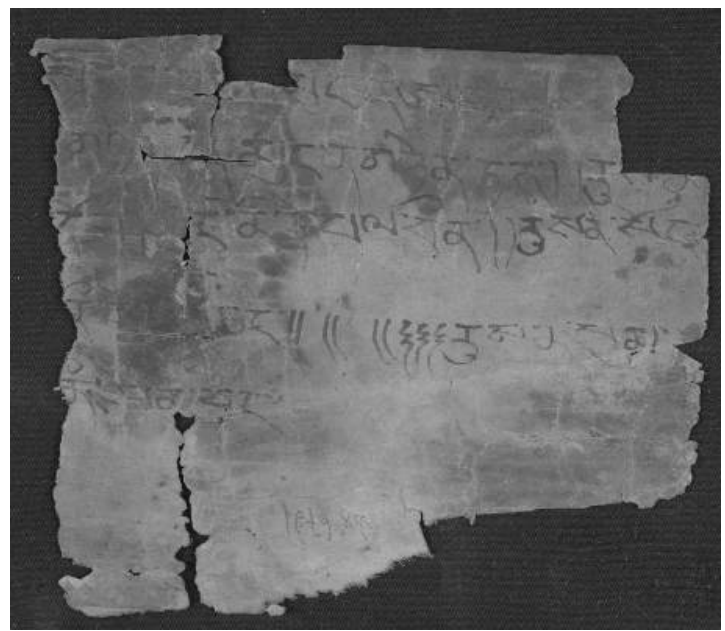

1. [...] sgring $\cdot\left[\right.$ bzang?|_]][m]yIng $\cdot \mathrm{nI} \cdot \wedge a \cdot h a m \_[]$

2. [...]gnyer'sgra $\mid$ my $<I>$ ng $\cdot n I \cdot g n y e n \cdot \tan \cdot\left|\_\right|$ $\mathrm{ru}<s^{*}>\mathrm{n}[i]$

3. [...] dog $\mid$ my $<i>$ ng·ni·dpal·byIn'||rus`nI·song $\cdot$

4. [...]nI'song $\cdot ? ?$ chang $\cdot\left\|\_\right\| \_\| \& \& \&$ rus`n $[I]^{\wedge} \mathrm{yIm}^{8}$

5. $[\ldots] \mathrm{nI} \Gamma^{\wedge}$ an`cung

\section{8. Дх-3111 (ДХН 2524)}

A fragment $(10.9 / 6.3 \times 6.2 / 4.4 \mathrm{~cm})$ of Chinese text. On the Verso side, seven Tibetan lines are found.

\section{Recto}

Fragment of Chinese text Taigong Jiajiao 太公家教.

\section{Verso}

Seven lines in Tibetan. The end of the text is missing. The list includes Chinese inhabitants most probably in Dunhuang with their levying based on rkya, a tax unit of Tibetan Empire. On the term rkya, see IWAO 2009.

\footnotetext{
${ }^{8}$ See the footnote 2 of the paper.
} 


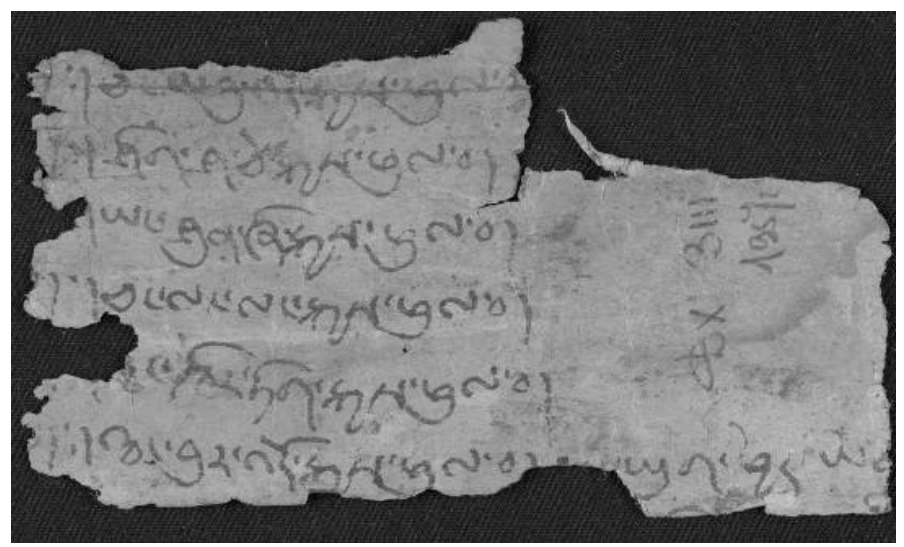

1. [@] :|cang·ya?'bu'’d[o]'rkyas'phul·[ba]>

2. [@]:|:shig'sha'tse'rkyas'phul·ba|_|

3. [@|:]|yang·shun'zhi·rkyas·phul·ba|

4. [@] $\cdot|\cdot|$ cang·lang·lang·rkyas'phul·ba|

5. [@][l:|wa]ng·khir'tig'rkyas'phul·ba|

6. [@]:||wang·bur''do'rkyas'phul

ba[L_l-] yug $\cdot$ phyed $\cdot y e[-][\ldots]$

7. $[\ldots] \mathrm{i}[\ldots] \mathrm{i}[\ldots]$

\section{9. Дx-7759}

A fragment $(15 / 7 \times 9.4 / 2.5 \mathrm{~cm})$ with two tiny fragments (see the left middle part). All sides are torn off.

\section{Recto}

Six lines in Chinese. The text is unidentified.

\section{Verso}

Eight lines in Tibetan with several twofold circles. The beginning and the end of the text are missing. The text is apparently the results of the divination with dice ${ }^{9}$. Ai Nishida mentions this fragment in her dissertation (NISHIDA 2012, 205) ${ }^{10}$, with SI O 145 kept at IOM RAS.

\footnotetext{
${ }^{9}$ For the divination with dice in Old Tibetan texts, see NISHIDA 2008.

${ }^{10}$ However, she makes a mistake when calling it SI 56a, hence her entire analysis of this item as a piece from N. F. Petrovsky's collection is based on a misunderstanding. She did not work with the manuscript in St. Petersburg but used its picture taken by Ts. Takeuchi. This
} 


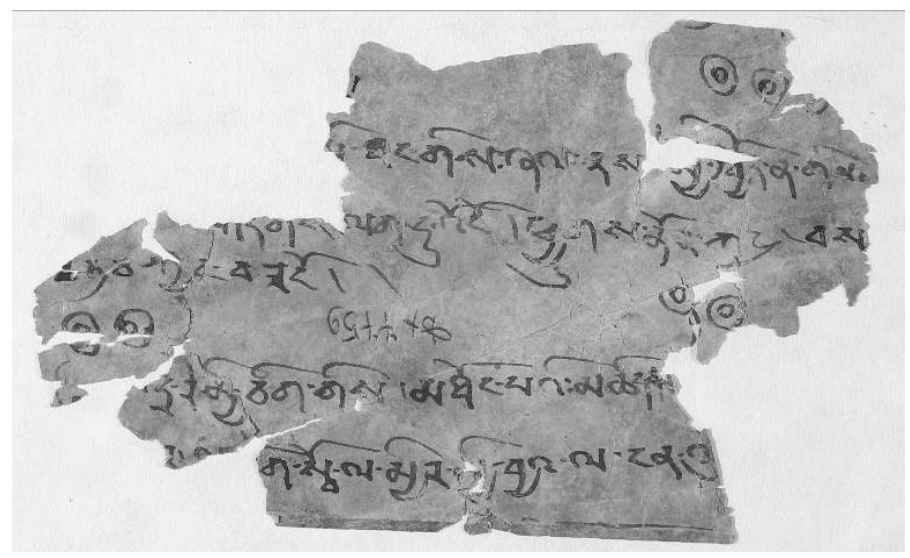

1. $[\ldots]$

2. $[\ldots]$

$\odot \odot[\odot]$

3. [...-]is thang $\cdot$ gis $\cdot \mathrm{zhal} \cdot \mathrm{nas}[\cdot] \mathrm{myi} \cdot \mathrm{khyod} \cdot \mathrm{na} \cdot \mathrm{gis} \cdot[\ldots]$

4. [...gdags $\cdot]$ lag $\cdot d u \cdot$ 'o-ngo _lphyugs'nor'kyang $\cdot b s[-\ldots]$

5. [...]btab kyalng bza-ngo_

6. $[\ldots] \odot \odot$

$\odot \odot$

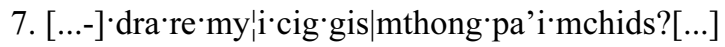

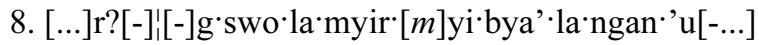

\section{0. Дx-9533}

An oblong fragment of a sheet $(16 \times 9.7 / 9 \mathrm{~cm})$. The right and bottom sides are torn off. On the Recto side, there are two lines in Tibetan and a line in Chinese. Both are apparently written by pen with the same hand. These are most probably the review of the missing volumes of Da Banruo Jing. The results are strangely different between Chinese and Tibetan.

picture is included in the text of her dissertation (NISHIDA 2012: 281) and the true call number (Дх 7759) is clearly seen there since it is written with pencil right on the manuscript. Ai Nishida did not provide the transliteration of the text. Moreover, the arrangement of the main part of the fragment with one of the two small fragments that are torn off is not correct on the picture used by her. For the digital copy published in our paper all the fragments were assembled in a correct way. Therefore, our edition can be considered the first proper publication of this item.

We would like to thank Alla Sizova (IOM) for her explanation of Nishida's mistake: it turned out that Дx 7759 was put, in a provisional way, inside a sort of an envelope on which the call number SI 56a was written. It refers to a completely different item in N. F. Petrovsky's collection. 


\section{Recto}

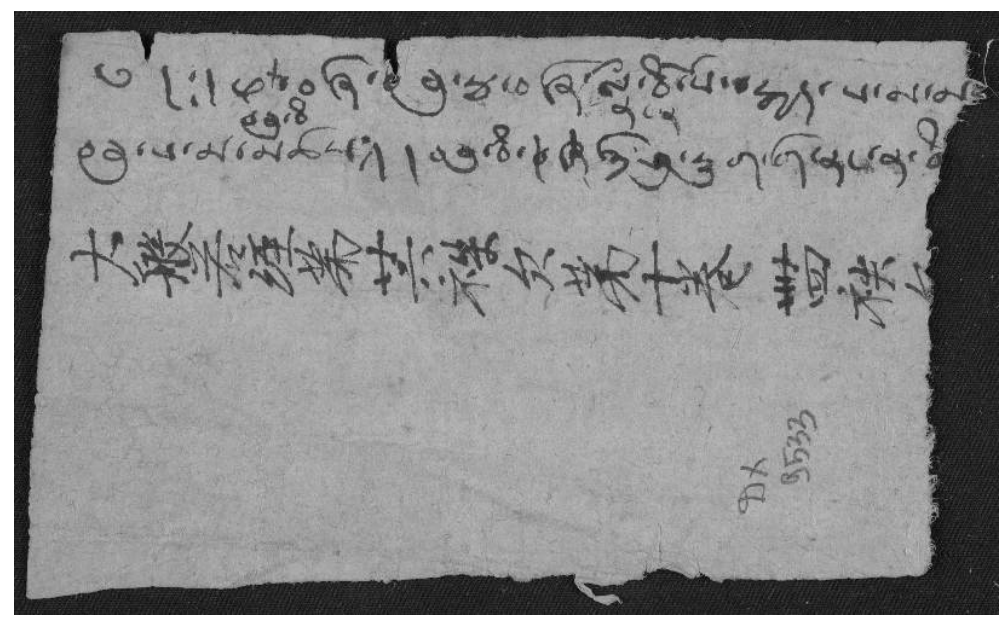

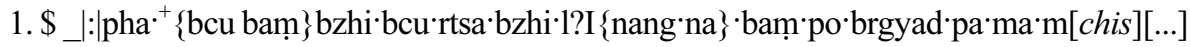

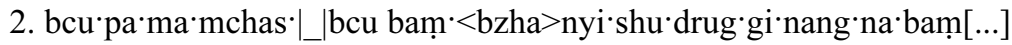
大般若經第廿六袟缺第十卷四十四袟缺 $[. .$.

\section{1. Дx-10385}

A rectangular fragment $(10.7 \times 7.5)$. Recto: a four-line letter draft in Tibetan. For the format of the Old Tibetan letter, see TAKEUCHI 1990. Verso is blank.

\section{Recto}

Four lines in Tibetan. The beginning and end of the text is missing. The left and right sides are torn off.

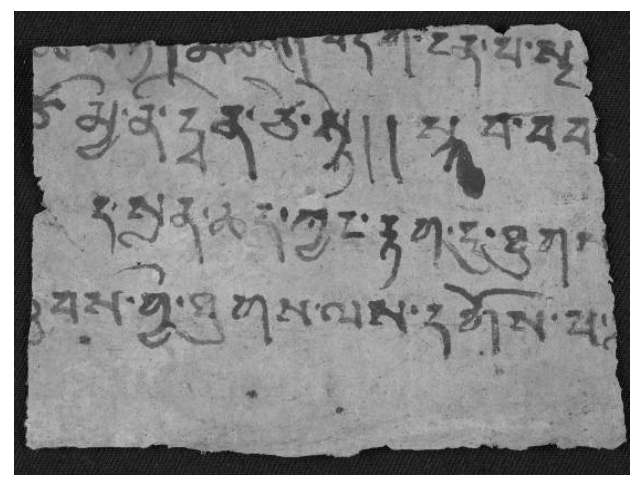

1. [...]ch?[btag?]mch?[-||]_bdag $\cdot$ ngan pa'snga $[\ldots]$

2. [...][ts? ]'myI'ni'dvan'tse'ste $\mid$ skab· bab[...]

3. $[\ldots]$ _da $\cdot$ slan ${ }^{\prime}$ chad $\cdot$ kyang $\cdot r t a g \cdot d u \cdot$ thugs $[\ldots]$

4. [...][-]ubs'gyI'thugs las'dgos'pa' $[-][\ldots]$ 


\section{2. Дx-11758}

A fragment $(8 \times 6.6 \mathrm{~cm})$ of Chinese Buddhist scroll on which Tibetan is written on both Recto and Verso. The Tibetan text is unidentified.

\section{Recto}

A Tibetan line between Chinese Buddhist text Jingang Banruo Jing 金剛 般若經.
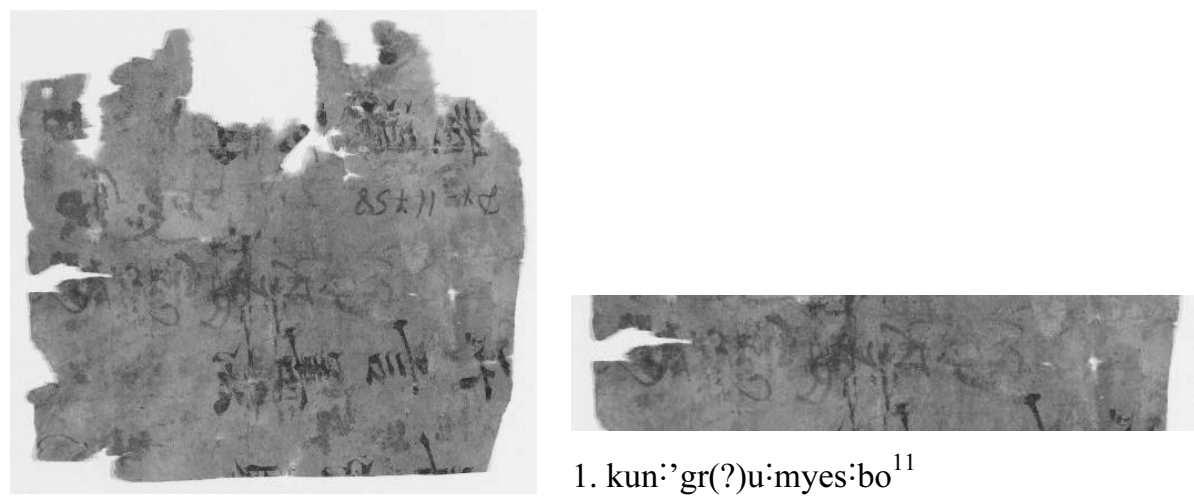

1. kun:'gr(?)u:myes:bo ${ }^{11}$

\section{Verso}

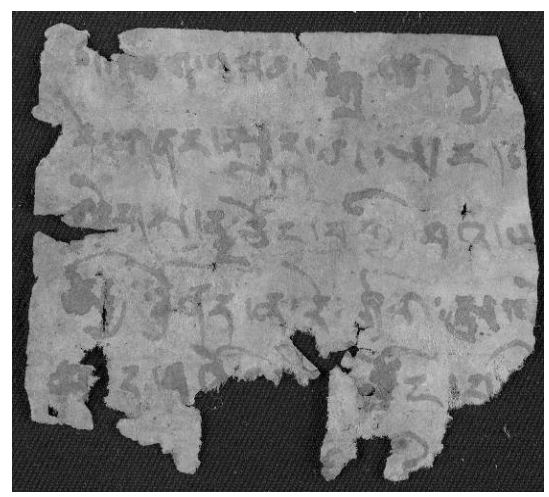

1. \$||khag'’pan:sgra:la'mye[s...]

2. de'gnang'slang'ma:yang $\mid[-][\ldots]$

3. legs|da-ng:tsong'bgyilba'lya[...]

4. myi:nyond'na're:shig:a'[-][...]

5. m[-]d'gn?o[- - -]_ts?ong'pa[-]I[...]

6. $[\ldots][[\ldots]$

${ }^{11}$ The syllable $b o$ is the final one on the recto while what is seen after it is nothing but a fragment of the text on the verso that appears visible. 


\section{References}

Bacot, Jacques, Thomas, Frederick William, Toussant, Gustave-Charles 1940: Documents de Touen-houang relatifs à l'histoire du Tibet. Paris: Librairie orientaliste Paul Geuthner.

Blondeau, Anne-Marie 1972: Matériaux pour l'étude de l'hippologie et de l'hippiattrie tibétaines. Genève-Paris: Librairie Droz.

Dotson, Brandon 2009: The Old Tibetan Annals: An Annotated Translation of Tibet's First History, with an Annotated Cartographical Documentation by Guntram Hazod. Wien: Österreichische Akademie der Wissenschaften.

IwAo Kazushi 2009: "An Analysis of the Term rkya in the Context of the Social System of the Old Tibetan Empire." Memoirs of the Research Department of The Toyo Bunko, 67, 89-108.

IwAO Kazushi 2011: "A Newly Identified Fragment of The Tibetan Royal Annals in St. Petersburg.” In: Imaeda Y., Kapstein M.T., Takeuchi T., editors. New Studies of the Old Tibetan Documents: Philology, History and Religion: Old Tibetan Documents Online Monograph Series, vol. 3. Tokyo: Institute for Languages and Cultures of Asia and Africa, 245-55.

NishidA Ai. 2008 “Ko Chibetto go Saikoro Monjo no Kenkyū 古チベット語の骰子文書の研 究”. Nihon Chibetto Gakkai Gakuho 日本西蔵学会会報, 54, 63-77.

NisHidA Ai 2012: Ko Chibetto go Uranai Monjo no Kenkyū 古チベット語占い文書の研究, Ph.D. Dissertation (Kobe City University for Foreign Studies).

SAVITSKY, L.S. 1991: Opisanie tibetskikh svitkov iz Dun'khuana v sobranii Instituta vostokovedeniia AN SSSR [The Description of Tibetan Scrolls from Dunhuang Preserved at the Institute of Oriental Studies of the USSR Academy of Sciences]. Moscow: Nauka, GRVL.

TAI Huili 邰惠莉(ed.) 2019: Ecang Dunhuang Wenxian Xulu 俄藏敦煌文獻敘錄. Gansu Jiaoyi Chubanshe.

TAKEUCHI Tsuguhito 1990: "A Group of Old Tibetan Letters Written under Kuei-i-chün: A Preliminary Study for the Classification of Old Tibetan Letters." Acta Orientalia Academiae Scientiarum Hungaricae, XLIV: 175-90.

TuranskAYA, A.A. 2020: "Newly found Dunhuang fragments of Śatasāhasrikā Prajñāpāramitā in the Collection of the IOM, RAS". Written Monuments of the Orient, Vol. 6, 2020, no. 1. P. 88-102.

Vorobyova-Desyatovskaya, M.I. 1995: "Tibetan Manuscripts of the 8-11th centuries A.D. in the Manuscript Collection of the St. Petersburg Branch of the Institute of Oriental Studies". Manuscripta Orientalia, vol. 1, no. 1, 46-48.

ZoRIN, A.V. 2012: "The Collection of Dunhuang Tibetan Texts Kept at the IOM, RAS". Dunhuang Studies: Prospects and Problems for the Coming Second Century of Research. St. Petersburg: Slavia Publishers, 365-367.

Zorin, A.V. 2017: "Fragments of Tibetan Texts Refound at the Dunhuang Collection Kept at the IOM, RAS: Eleven Identified Fragments of Buddhist Canonical Texts" Written Monuments of the Orient, 2017, 1 (5), 49-72.

Zorin, A.V. 2018: "A Dunhuang Tibetan Manuscript of "Ārya-samādhyagrottama" Kept at the IOM, RAS”. Written Monuments of the Orient, 2018, 1(7), 25-34.

Zorin, A.V., Sizova, A.A. 2019: "On the history of the formation and processing of the Collection of the Tibetan Texts from Khara-Khoto kept at the IOM, RAS". Written Monuments of the Orient, 2019, 2(10), 3-18. 